\title{
Wax, Wings, and Swarms: Insects and their Products as Art Media
}

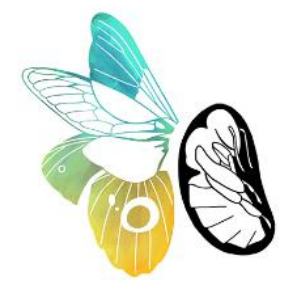

Barrett Anthony Klein

Pupating Lab

Biology Department, University of Wisconsin-La Crosse, La Crosse, WI 54601 email: barrett@pupating.org

When citing this paper, please use the following: Klein BA. Submitted. Wax, Wings, and Swarms: Insects and their Products as Art Media. Annu. Rev. Entom.

DOI: 10.1146/annurev-ento-020821-060803

Keywords

art, cochineal, cultural entomology, ethnoentomology, insect media art, silk 


\section{Abstract}

Every facet of human culture is in some way affected by our abundant, diverse insect neighbors. Our relationship with insects has been on display throughout the history of art, sometimes explicitly, but frequently in inconspicuous ways. This is because artists can depict insects overtly, but they can also allude to insects conceptually, or use insect products in a purely utilitarian manner. Insects themselves can serve as art media, and artists have explored or exploited insects for their products (silk, wax, honey, propolis, carmine, shellac, nest paper), body parts (e.g., wings), and whole bodies (dead, alive, individually, or as collectives). This review surveys insects and their products used as media in the visual arts, and considers the untapped potential for artistic exploration of media derived from insects. The history, value, and ethics of "insect media art" are topics relevant at a time when the natural world is at unprecedented risk.

\section{INTRODUCTION}

The value of studying cultural entomology and insect art

No review of human culture would be complete without art, and no review of art would be complete without the inclusion of insects. Cultural entomology, a field of study formalized in 1980 (43), and ambitiously reviewed 35 years ago by Charles Hogue (44), clearly illustrates that artists have an inordinate fondness for insects. Insects are too numerous, diverse, pervasive, colorful, and marvelous to be ignored by artists. From the engraving of a cricket on the bone of a now-extinct bison (7) to a cockroach controlling a robot (84), artists have explored or exploited our six-legged neighbors as symbols, metaphors, literal subjects, or for their bodies or bodily products in works of art throughout history and across cultures. So extensive is the influence of insects on art that art history could be studied through the lens of insect art, whether it be about art since antiquity $(9,57,65)$, contemporary art $(4,23,35-37,58,92,113)$, art with a regional focus $(24,27,79,98,116)$, from a taxonomic point of view (72), in light of environmentalism (60), or with respect to artist $(62-64,117)$. I define insect art as art that either uses insects, depicts insects, or conceptually pertains to insects (Figure $1 a-e$ ). A narrower definition of insect art might exclude incidental uses of insect media, in which an artist does not clearly use a medium for reasons that explicitly or conceptually relate to insects (e.g., shellac coating a plaster sculpture, beeswax in an encaustic painting, or carmine used to dye a textile; Figure $1 e$ ). 


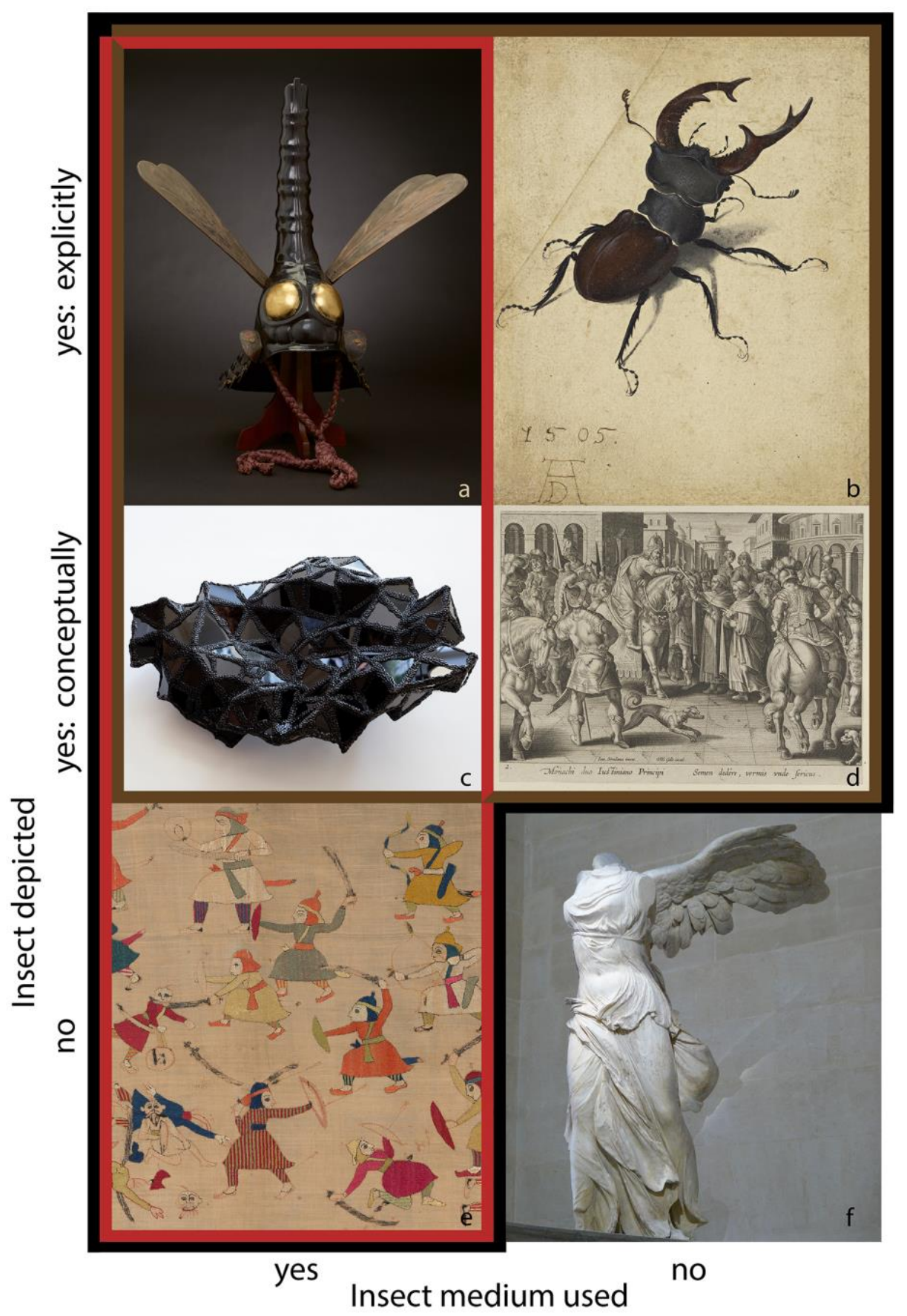

Figure 1. Examples within the visual arts of works that do or do not depict insects, explicitly or conceptually, and do or do not include insect media (insect product, body part, or whole body). Insect art can be defined broadly ( $a-e$; black border), or narrowly ( $a-d$; brown border). This review focuses on any visual art using insect media ( $a, c, e$; red border). (a) Helmet in dragonfly shape ( $17^{\text {th }}$ cen. Japan) explicitly depicts an insect and is composed partly of silk. (b) Stag Beetle (Albrecht Dürer, 1505, watercolor and gouache) depicts an insect, but was not made using an insect medium. (c) Of Insects and Men \#3 (Marlène Huissoud, 2016) was made with insects in mind, and with honey bee propolis. (d) Emperor Justinian Receiving the First Imported Silkworm Eggs from Nestorian Monks (Karel van Mallery, ca. 1595) 
is conceptually relevant to insects, but includes no insect medium. (e) Festival Banner Showing Krishna Rescuing and Marrying Rukmini (detail of $800 \mathrm{~cm}$-long banner, ca. 1800, India) lacks any explicit or conceptual depiction of an insect, but was embroidered with silk, and dyed red with carmine and lac. $(f)$ Winged Victory of Samothrace (ca. 200-190 BCE, marble) neither depicts an insect subject nor was it made with insect media. Images courtesy of (a) Minneapolis Institute of Art (open access), (b) J. Paul Getty Museum's Open Content Program, $(c)$ the artist, $(d, e)$ Metropolitan Museum of Art's Open Access program, and (f) Lyokö̈88, CC BY-SA $4.0<$ https://creativecommons.org/licenses/by-sa/4.0>, via Wikimedia Commons; Musée du Louvre (image cropped).

Since Hogue's landmark review, the Annual Review of Entomology has published several topics Hogue would identify as relevant to cultural entomology $(25,61,68)$, but few reviews of cultural entomology, ethnoentomology, or entomology's connections or relevance to the arts have been published anywhere since. We consciously or unwittingly forge connections with insects in every aspect of our existence, and reporting how insects affect human culture could have important implications for peoples' appreciation of insects, for invertebrate conservation, or for diversifying who practices the science of entomology. Cultural entomology could promote entomology as a broader discipline, relevant to anthropology, archeology, politics, economics, religion, language, dance, music, and the arts in all of its forms. The study of insect art can promote our understanding about our history and our relationship with nature. Moreover, it is the connections we make with insects, artistically and otherwise, that could help reduce our destructive tendencies to the natural world and, consequently, to ourselves (60). Insects have had a far-reaching influence on the history of art, and, although the practice of including actual insects or their products in art is widespread, it has largely been overlooked or ignored.

\section{Aim of this review}

My objective here is not to offer a comprehensive overview of insect art. It is not about depicting insects - abstractly, fantastically, whimsically, or realistically. This review is about exploring the diversity and potential of insects as art media. I will borrow and redefine a term, "insect media art" (84), to refer to insect products, bodily parts, or entire bodies used as art media (Figure $1 a$, $c, e)$, and devote most of this review to insect media art that is explicitly or conceptually relevant to insects (Figure $1 a, c$ ). Due to space constraints, I restrict my survey to insect media used in the visual arts. I only briefly mention arachnids (56), and I do not discuss media theory. The history of film and photography is crawling with insects, but I include only examples when this medium is the remaining evidence of an art project featuring insect media. 


\section{ART MEDIA}

All art changes with time, and a work's vibrancy and longevity depend on its physical constitution and interaction with the environment. Like all art media, insect media can be ephemeral, transient, volatile, or unpredictable, like the fading cochineal in paintings by Van Gogh $(31,71)$ and Renoir $(17)$, or can outlast us all, as with the structural colors of iridescent beetle elytra. To understand the technical aspects of a work of art is to better appreciate its history, and to know how to care for it (34). The value of using insects or their products as art media can depend as much on the utilitarian nature of the materials as it does on the conceptual intentions of the artist.

\section{TRACES}

Let's begin with an impression. Adam Cohen and Ben Labay practice gyotaku, the traditional Japanese method of inking and pressing fish against paper, and extend the practice to insects (Inked Animal). Although these impressions and the following examples lack significant remnants of insects or their products (i.e., technically not insect media art), Inked Animal uses insect bodies to create art, just as the following depend on insect behaviors.

Insects flit, scramble, and maneuver in telltale ways, and some artists have intentionally immortalized these paths for posterity. The Ngali tribe of Central Australia has a grasshopper totem, and once decorated a churinga (sacred object) with symbolic grasshopper paths and tracks (100). Artists have followed ants with pencil (Katharina Meldner; 77), red oil pencil (Yukinori Yanagi; Figure $2 a$ ), and digitally (Edhv's 2D and 3D design pieces), and recorded a moth's attraction to light by rapid-prototyping the flight path (Geoffrey Mann, Attracted to Light from the Long Exposure series, 2005). Artists also record tracks by manipulating insects as "living brushes" by painting portions of their bodies and orchestrating their perambulations across a canvas (Steven Kutcher, "insect footprint art”; Figure $2 b$ ), or by allowing insects to move through paint (Rebecca O'Flaherty's education-focused “maggot art”) or charcoal (Alison Reiko Loader, Caterpillar Cartography, 2017). Traces can also take the form of tunnels, channels, cavities, and galleries, as excavated by ants or bark beetles. Walter Tschinkel pours molten metal down ant nest entrances and excavates the resulting casts, which serve as scientificallyinformative art pieces $(109,110$; Figure $2 c)$. Beetle larvae often leave galleries in trees that 
might be considered art in their own right (48), and Ann Savageau has created bark beetle "totems," and Suze Woolf is creating a series of Bark Beetle Books, most of which preserve or record from beetle larvae's actual galleries (Figure $2 d$ ).
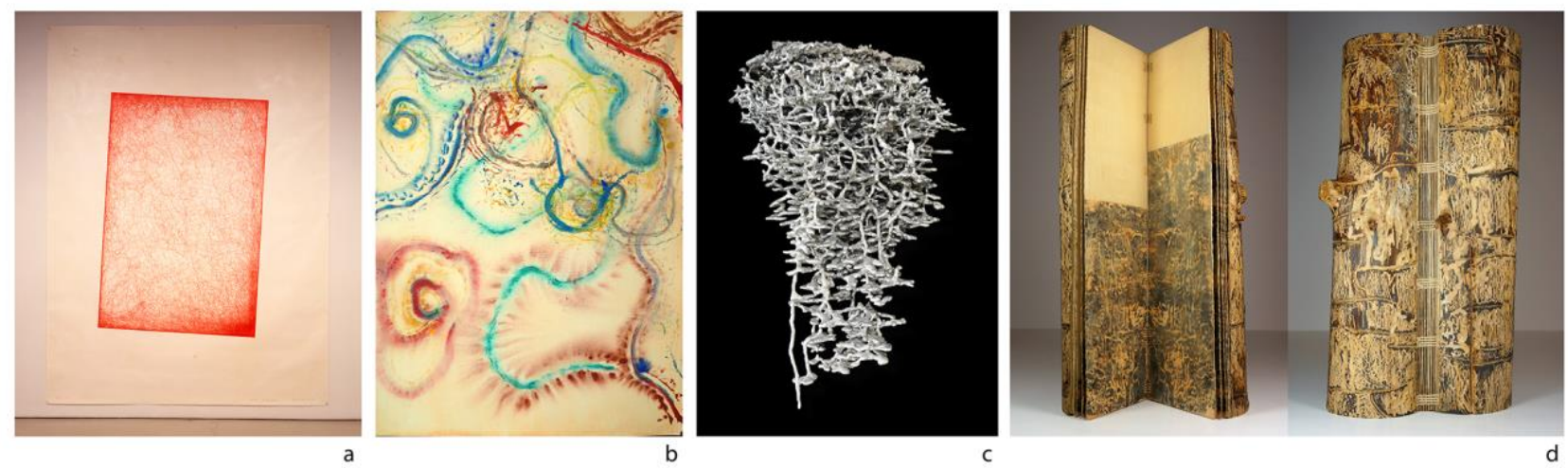

Figure 2. Traces. Though these works were not made from the bodies or bodily products* of insects, they represent artistic recordings or realizations of traces left by insects. (a) Wandering Position - Alcatraz (Yukinori Yanagi, 1997, (CYanagi Studio) follows the path of one harvester ant (Pogonomyrmex sp.) with a red oil pencil (*exception: coated with beeswax for protection). (b) Starry Night (Steven Kutcher, 2004) marks the paths of 2-3 hissing cockroaches (Gromphadorhina portentosa) across a canvas, their tarsi and ventral abdomens daubed with paint at the start of their journey. (c) Aluminum cast of a nest of fire ants (Solenopsis invicta) (Walter Tschinkel, 2012; photo by Charles F. Badland). (d) Bark Beetle Book Volume XIV: Ars datum est (Suze Woolf, 2017) is a split log with galleries made by fir engraver beetles (Scolytus ventralis), and pages visualizing destruction of timber areas using rubbings of beetle-bored logs. All images are used with permission from the artists.

\section{PRODUCTS}

Insects have evolved an array of glandular secretions and exudates from head to tarsus, and some of these bodily products have been exploited by humans, including artists. Below are the most notable products and their applications in art.

\section{Silk}

"The spider as an artist"1 is responsible for strange and marvelous contributions to art history, from delicate "cobweb art" (14) (note: some works were actually made from silk of the ermine moth, Yponomeuta evonymella; 12$)$ to a tapestry spun by over one million spiders $(54,66)$. It is insects, however, that have dominated silk art for millennia. Twenty-three different silks have

\footnotetext{
${ }^{1}$ Cobwebs, by Emily Dickinson
} 
evolved within Insecta (103), but silks from relatively few species, exclusively moths (Lepidoptera), have made inroads to industry. Dozens of wild species from several moth families in India, East Africa, and Madagascar contribute to sericulture (104), and moth cocoons from various species are traditionally used for non-sericultural purposes by cultures around the world (86).

One species, Bombyx mori, bred for 4700 years, overshadows all others. Utterly dependent on humans, the domesticated silkworm moth produces most of the silk used in fashion, the fiber arts, and as canvas. Larvae use a pair of modified salivary glands in the head to secrete fibroin fibers, glued together with sericin, which is removed in sericulture by immersing cocoons in hot water (51). Silk is strong, lightweight, elastic, takes dyes, resists creasing, insulates well, and can be used as a canvas for printing and painting. Silk may contribute to the majority of insect art, of which this review showcases only a few historical examples (Figure $3 a$, Table S1). A search for "silk" in the Metropolitan Museum of Art's online database presently offers 36,312 results. As an example of how diversely silk can be used in art, Jen Bervin produced a book with the image of a silk cocoon printed on silk, a poem printed on a silk biosensor, and glass containers with cocoon, skein, scroll, and liquid silk fibroin (Seven Silks, 2018). Kazuo Kadonaga (20) and Xu Bing have explored aspects of sericulture in their work since 1986 and 1994, respectively, by allowing B. mori larvae to spin within certain constraints or in certain contexts (Figure $3 b, c$ ), and Marlène Huissoud uses cocoons discarded by the eclosed adults in her sculptures (Figure 3).

Wax

Wax, being malleable, easily melted or pigmented, and insoluble in water, offers multifarious uses to artists, including as sculpting, casting, and mold-making material, painting medium, binding agent, and protective coating. Like silks, waxes are secreted by many different insects, but one species generates the vast majority of wax used by artists - in this case, western honey bees (Apis mellifera).

If creation of honeycomb by honey bees (Apis spp.) is "the most wonderful of all known instincts (22)," the wealth of waxworks in art reflects the value of this insect product. Egyptians entombed figures fashioned out of beeswax. The human anatomical wax models produced for La Specola, 
in Italy, include waxes secreted by scale insects (Ceroplastes ceriferus and Ericerus pela; 40), but Gaetano Giulio Zumbo, considered the greatest of the anatomical wax sculptors, combined substances with pure beeswax to achieve the translucency of human tissue (10, 40). Sculptures by Edgar Degas, Joseph Beuys (88), Wolfgang Laib (The Passageway, 1988), and Kiki Smith (Honeywax, 1995) were made with beeswax (Figure $3 d$,e). Beeswax is the traditional ingredient of encaustic painting (59), practiced in ancient Greece and Rome, and continued by James Ensor, Diego Rivera, and Jasper Johns. Barbara Walton, one of many encaustic painters who have depicted honey bees in their work (Table S1), describes beeswax as the most versatile and "the most pure, natural and sustainable of the waxes in addition to having an intoxicating and sensual aroma (5)."

The honeycomb itself, unmelted and unadulterated, attracts artists who aspire to collaborate with colonies of honey bees. "Apisculptures" rely on honey bees to build comb on sculpted forms (Garnett Puett, Tomáš Libertíny, Bärbel Rothhaars; 13), prints (Ladislav Hanka), paintings or embroidered works (Ava Roth), in modified hives (Hilary Berseth, Ren Ri), or on found objects, which the bees can transform in unpredictable ways (Aganetha Dyck, 83; Figure $3 e$ ).

Beeswax produced by stingless bees (Meliponini, Apidae) is softer with lower melting point than that produced by honey bees, so bees combine the wax with resin or other materials when constructing their nests (101). This nest material was responsible for the troves of pre-Columbian gold artifacts of Mexico and Central America, which were cast using the lost wax process (94). The lost wax process dates to the third millennium BCE in the Middle East (81), and was used for Greek, Etruscan, and Roman bronze works. Javanese batiks were reported to use Trigonula iridipennis wax, and the Worróra of Australia protected rock paintings by creating semicircles of stingless bees' wax as guards against rain. Aboriginal Australians also used beeswax to sculpt objects for rituals, sorcery, and love magic (18). Cubans began using Melipona beecheii wax to produce lithographic inks and lithographic pencils (94).

\section{Honey}

Producing wax requires consumption of fuel, and honey bees collect nectar or the sweet secretions of other insects and convert this to honey, using glandular secretions in the honey- 
stomach (78). Honey's properties make the sticky substance a useful binder in art. Greeks may have used honey in wall paintings in the Palace of Nestor (Pylos, before $1180 \mathrm{BCE} ; 11$ ), and honey is still used to bind particles of pigment in some watercolor formulas. M. Graham \& Co. report that honey allows for high pigment loads, produces smooth washes, and their paints remain moist due to honey's hygroscopic nature. Pure pragmatism aside, honey has also been the main attraction of art pieces, most notably in works by Joseph Beuys. Beuys' Honey Pump at the Workplace (1977) transported two tons of honey for 100 days through transparent tubes in Kassel, Germany, creating a pumping, circulating structure analogous to our own circulatory system (102).

\section{Propolis}

Yet another product of honey bees is their resinous, gap-filling propolis. Marlène Huissoud experiments with unconventional materials for her art and design, and her work with propolis appears unique to both worlds. Huissoud has found success applying basic glass blowing and engraving techniques to propolis, which, with its lower melting point, requires a modified kiln and more time to manipulate (47; Figure $3 f)$.

Coloring agents: carmine, lac, and insect gall ink

Of all the natural red dyes, the most brilliant come from scale bugs (Superfamily Coccoidea), historically the only insect-derived source of pigments or artistic finishes. The bodies of female bugs are dried and pulverized, and in the case of kermes and cochineal bugs, this extract is used to produce carmine - a substance of such crimson allure that it featured largely in the history of art and commerce, both in the old and new worlds. Phoenicians traded kermes (primarily Kermes vermilio) extensively throughout the Eastern hemisphere, and Porphyrophora spp. (especially Polish kermes, P. polonica) colored Siberian and central Asian textiles (87). Armenian cochineal (P. hamelii) decorated illuminated manuscripts produced in Armenian monasteries. Armen Sahakyan, at the Mesrop Mashtots Institute of Ancient Manuscripts, may be the only living person who can create the red ink from $14^{\text {th }}$-century recipes, as seen in a recent series of works by Aslı Çavuşoğlu (Yavuz Parlar, pers. comm.; Figure 3). The bug is endangered in Armenia, and the knowledge of how to extract the color is lost to neighboring Turkey, where the bug is plentiful. Çavuşoğlu uses Armenian cochineal in some pieces and Turkish red pigment in others, 
and describes the pieces as relevant to the "co-existing nature of the plant and insect relations, hinting at a possible analogy between Turkish and Armenian people" (Çavuşoğlu, pers. comm.).

Harvesting these scale insects was laborious, so when Spanish conquistadors hauled back tons of cochineal (Dactylopius coccus, although D. confusus was also cultivated in Peru; 95), which had been used since at least the $2^{\text {nd }}$ century BCE, the old world was taken by storm. Cochineal, being deep crimson, easy to use, and plentiful, became the chosen dye for artists soon after it arrived in Europe, and, later, for the impressionists. The bugs had been artificially selected in the Americas to evolve larger bodies containing more carminic acid. Andean dyers developed techniques of adding a mordant to help bond carmine to animal hair (carmine bonds to silk and mammal hairs better than to plant fibers), with other additives to shift the bright pink to a range of hues (87). The practice of experimenting with cochineal to achieve different hues continues today by textile artists like D.Y. Begay (Palette of Cochineal, 2013), and traditional dyes and materials are exhibited in installations by Elena Osterwalder (Amatl Installations). Jennifer Angus used cochineal to color the walls of an entire gallery space (In the Midnight Garden, 2015), and produced a tiny carmine-dyed book (Figure $3 i$ ) for the collaboration Insect Dreams Cabinet (2018). It took centuries for anyone to recognize that the source of scale-derived dyes was not berries or worms $(19,87)$, so from the perspective of this review, any insect-dyed work prior to the discovery of cochineal to be an insect would constitute insect media art lacking explicit or conceptual relevance to insects (Figure $1 e$ ), unless another insect species or insect-related subject was depicted.

Dyes made from scale insects fade when exposed to light (85). Particles that once contained cochineal pigment molecules can fall apart and become translucent, resulting in dramatic changes to the color palette of classic paintings (17). Other coloring agents are relatively permanent. Lac insects (commonly Kerria spp. and Paratachardina spp.; 8) are harvested with the lac they secrete because their bodies produce a dye (Figure $1 e$ ), and colors prepared from this dye are considered light fast (55), or at least "rather more permanent than those from cochineal (85)." As with carmine dyes, historical $(8,15)$ and modern $(55)$ recipes exist for using lac dye, as does advice for which paint media are best used with lac dye. A permanent ink used in drawings by Leonardo Da Vinci, Rembrandt, Dürer, and Van Gogh (2) that is still in use today 
because of its permanency comes not from the bodies of insects, but tannic acid found in high concentrations in plant galls caused by gall wasp larvae (e.g., Andricus kollari, Cynips quercusfolii).

\section{Insect lacquers}

Female lac bugs (commonly Kerria lacca, Kerridae) produce a resinous, protective secretion of lac that has been processed into shellac for over 3000 years. Shellac has been used as protective coating, decorative finish (e.g., on Tibetan armor), lithographic ink, even as minimalist smudge in Edward Ruscha's Shellac (Master Mixed orange) (1969). Shellac can be worked and reworked in layers, and is suspected to outlast lac dye (see above) in greatly aged historic relicts (8). Giant margarodid scale bugs (Llaveia axin) were used to produce comparably fine, durable finishes in the Mayan civilization (69), but the source of this lacquer was fat from within females' exceptionally large bodies.

\section{Stains}

House flies (Musca domestica) leave stains, a combination of oral regurgitate (saliva) and feces. Place over 200,000 flies together, feed them sugar-watercolor mixtures with select hues in mind, and the resulting canvases they land on become works reminiscent of pointillism. John Knuth's fly paintings result from careful planning and understanding his dipteran subjects (105).

\section{Paper}

Saliva is a key ingredient when paper wasps (Vespidae) construct nests. Most paper wasps combine saliva with masticated plant material to form textured, colorful nests, which they typically abandon in temperate areas as the seasons change. Entire nests appear, albeit infrequently, in art, as does nest paper. Nests can be electroplated (Ashlyn Bapst), cut and arranged (Ann Savageau; Figure $3 j$ ), applied to surfaces as papier-mâché (e.g., wearable art by the author), or pulped and made into raw material. For one of their wasp works, Alastair and Fleur Mackie fed ca. 300 abandoned nests into a paper mill, from which they constructed a doll house (Figure $3 k$ ). The most self-referential work in this category goes to Kristian Brevik, who constructed a paper wasp out of wasp nest paper (Paperwasp, 2013). 

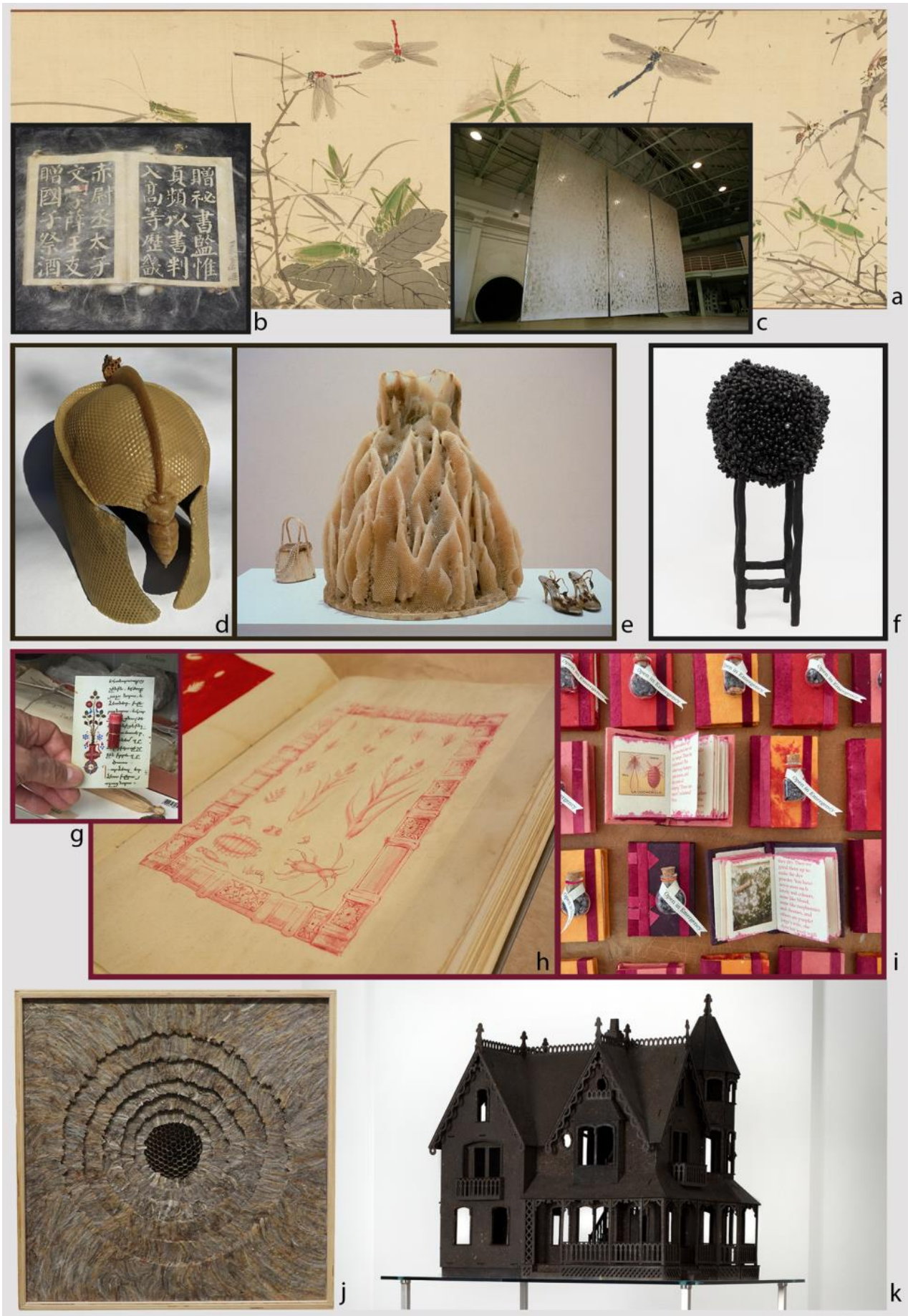

k

Figure 3. Insect art using insect bodily products. Silk: (a) Insects and Grasses (Yamamoto Baiitsu, 1847); (b) Silkworm Book: The Analects of Confucius (Xu Bing, 2020) "investigates the significance of silk and paper as mediums in practicing calligraphy" with live B. mori larvae (installation view at Asia Society Museum, NY, (CXu Bing Studio); (c) Silk No.3 ABC (Kazuo Kadonaga, 2006) offered viewers an opportunity to witness 50,000 silk-spinning B. mori larvae create a work independent of the artist's "arbitrary" vision. Wax: (d) Hive helmet (Barrett Klein, 2020) is armored with beeswax and beeswax foundation, and adorned with honeycomb (A. mellifera); (e) The Glass Dress, Lady in Waiting, with shoes and handbag (Aganetha Dyck, 
1992-1999) is the culmination of years of comb-building by honey bees on an object placed within a hive. Propolis: (f) Cocoon Cabinet \#5 (Marlène Huissoud, 2017) is composed of abandoned B. mori cocoons coated with A. mellifera propolis. Carmine: $(g)$ Vial of Armenian cochineal ( $P$. hamelii) carmine, donated to Harvard Art Museum's pigment collection after use in (h) Red/Red (Aslı Çavuşoğlu, 2015), here depicting the interdependence of insect and plant, fades beside a more resilient Turkish red pigment (seen on facing page), hinting about the relationship between Turkish and Armenian people (Aslı Çavuşoğlu, pers. comm.); (i) RED: A lost scene from In Search of Goliathus Hercules (Jennifer Angus, 2016) is a carminedyed tale of sleepy cochineal bugs, complete with emergency vial of cochineal. Paper: (j) Mandala (Ann Savageau, 2009) is part of a nest paper triptych (D. maculata); (k) House (Alastair and Fleur Mackie, 2008) is composed of ca. 300 abandoned, pulped wasp nests, made into sheets and cut to match the coordinates of a wooden doll house kit $(235 \times 125 \times 100 \mathrm{~cm})$. For additional examples of insect media art using products, see Figures $1 a, c, e, 5$ a (waxy cyst covering), and $5 f$ (caddisfly silk). Images courtesy of (a) Metropolitan Museum of Art's Open Access program, (b) (c) Museum Associates/LACMA, ( $d-k)$ the artists, and photographers (c) Kazufumi Oizumi, (e) Peter Dyck, $(h)$ Sahir Uğur Eren.

\section{BODY PARTS}

"Insect" and "entomology" both etymologically refer to "cut up" or "divided into segments." The following are examples in which artists have used segments, pieces, or bits of insect anatomy in their art.

\section{Body segments}

Body segments can be swapped, interspecifically rearranged, or combined with other items to form fantastical chimaeras, as created by Cedric Laquieze (Figure $4 a$ ), Jim Rittimann, Emmanuelle Dupont (Phalaenopsis, 2008), Tom Friedman (Dead Fairy, 2004), Anna Werzowa (Cybugs, 2011), Lisa Murch (Species, 2005-2008), and Jennifer Angus. Maohou ("hairy monkey") artists (e.g., Cao Yijian) assemble creatures with cicada exuviae and magnolia buds, a folk art practiced in China since the Qing dynasty. Donna Conlon constructed hyper-appendaged mutations (Nature Improvement Project, 2007), and insect-human dolls and insect-toy figurine hybrids are the brainchildren of Laurent Gauthier and Amy Swartz, respectively.

\section{Wings}

Structurally, esthetically, or symbolically, wings have been the choice feature in insect media art, and have been embroidered in textiles, adhered to canvases, and strung as jewelry. Beetle elytra appear most frequently in traditional arts because of their durability and beauty. The structural colors of jewel beetles (Buprestidae, commonly Sternocera aequisignata or Chrysochroa fulgidissima) and other beetle families have made elytra suitable for embroidery in Indian 
textiles, the singing shawls of Pwo Karen hill tribes of Thailand and Myanmar, and various forms of adornment from Amazonia, Central America, and Mexico to Australia and New Guinea (91; Figure 4 b). Pieces of beetle elytra were used to represent emeralds in Indian paintings (76). The Tamamushi "jewel beetle" shrine of Japan (ca. 650) is the oldest known use of beetle wings, and was once decorated with 9000 elytra (3). The allure of elytra has not been lost on contemporary artists, and buprestids are flaunted on catwalks, and are strung with home-spun silk in embroidery by Michael Cook. Jan Fabre is the best known of the elytra artists, and he has coated everything from coffins (32) to the ceiling of the Royal Palace in Belgium (Figure $4 c$ ) with $S$. aequisignata elytra.

Butterfly wings, referred to as "living pointillism" by Charles Hogue (42), are more delicate than beetle elytra, and have been the choice item for collage work by Jean Dubuffet, and later, Damien Hirst and Lori Precious (Figure $4 e$ ), among others. The Yukpa of Venezuela and Colombia use hind wings of beetles and dragonflies as necklace ornaments (90). Joris Hoefnagel adhered actual insect wings within an illuminated manuscript to accompany his highly realistic painted insects [Painted Dragonflies with Real Wings Attached, from Animalia rationalia et insecta (Ignis), vol. 1, pl. LIV, 1575/1580], a practice found in Vienna, Munich, and manuscripts of Philip of Cleves (53). André Masson affixed (what appear to be) neuropteran wings to paper (Street Singer, 1941), and Stan Brakhage pressed insect wings between splicing tape for one of his experimental films (Mothlight, 1963). Mayme Kratz embeds cicada wings in urethane (Figure 4), Judith Klausner adheres honey bee, cicada and other wings to her arrangements, and Fabián Peña uses tiny pieces of cockroach wings (Periplaneta americana) as tesserae for his mosaics. Elsabe Dixon is leading an artistic response to the invasive lanternfly (Lycorma delicatula) by creating art using its wings. John Kalymnios and Anna Werzowa have each created insect wingflapping installations, by motor and by fan, respectively. Tessa Farmer creates micro-scale fairylands by attaching hymenopteran wings to creatures that one writer has speculated might be the "missing link between the human and the insect world (75)."

\section{Wing scales}

Wing scales are the namesake of Lepidoptera, and the often dramatically colorful scales can brush off with ease. Lepidochromy is a practice of transferring moth or butterfly wing scales 
onto paper prepared with adhesive (30), best known from $19^{\text {th }}$ and $20^{\text {th }}$-century examples. Transfer of scales can be followed by drawing the body, or, as in the most ambitious publication of lepidochromy, by hand-coloring engravings of the body (26).

Henry ("Harold") Dalton transferred not a wing's-worth of scales, but individual butterfly wing scales (and diatoms) to produce still-life micromosaics on microscope slides during the last quarter of the $20^{\text {th }}$ century. Dalton transferred each scale with a boar bristle, positioned by breathing through a tube, and adhered in place by crushing a portion of the scale against the glass slide (106; Figure $4 f)$.

Appendages

Wings are partly responsible for insects' outrageous evolutionary success, but other appendages are worth noting, including in art. Legs and antennae appear in Catherine Chalmers' cockroach collages, salvaging components of American cockroaches (P. americana) that perished naturally in her care (Figure $4 \mathrm{~g}$ ). Legs also appear as “Flylashes" (2010) on Jessica Harrison's eyes, and are used as a weapon wielded by Tessa Farmer's minute fairies (e.g., Unwelcome Visitors, 2014). Leg segments, being beautiful and durable, can be strung on fiber for jewelry. The Yukpa use the femora of large beetles, especially Podischnus agenor, as bead separators (90), and the Niyahlósú band of Nambikwara in Brazil have strung necklaces of ant leg segments (Figure $4 h$ ).

\section{Armaments}

The horns of large rhinoceros beetles (Dynastinae, Scarabaeidae) are fashioned into necklaces in South America (90). Another armament, of sorts, comes in the form of modified egg-laying devices. Judith Klausner saw the opportunity to comment on sacrifice, martyrdom, and altruism, symbolized by honey bee stingers as crown of thorns (Figure $4 i$; pers. comm.): "I extracted stingers from dead honey bees, which was tougher than I thought it would be. I had to crush the abdomen and root around in the wreckage for a tiny sliver and extract it with forceps. I used the stingers as the thorns in the crown of thorns, attached around a circlet made from one of my hairs." 

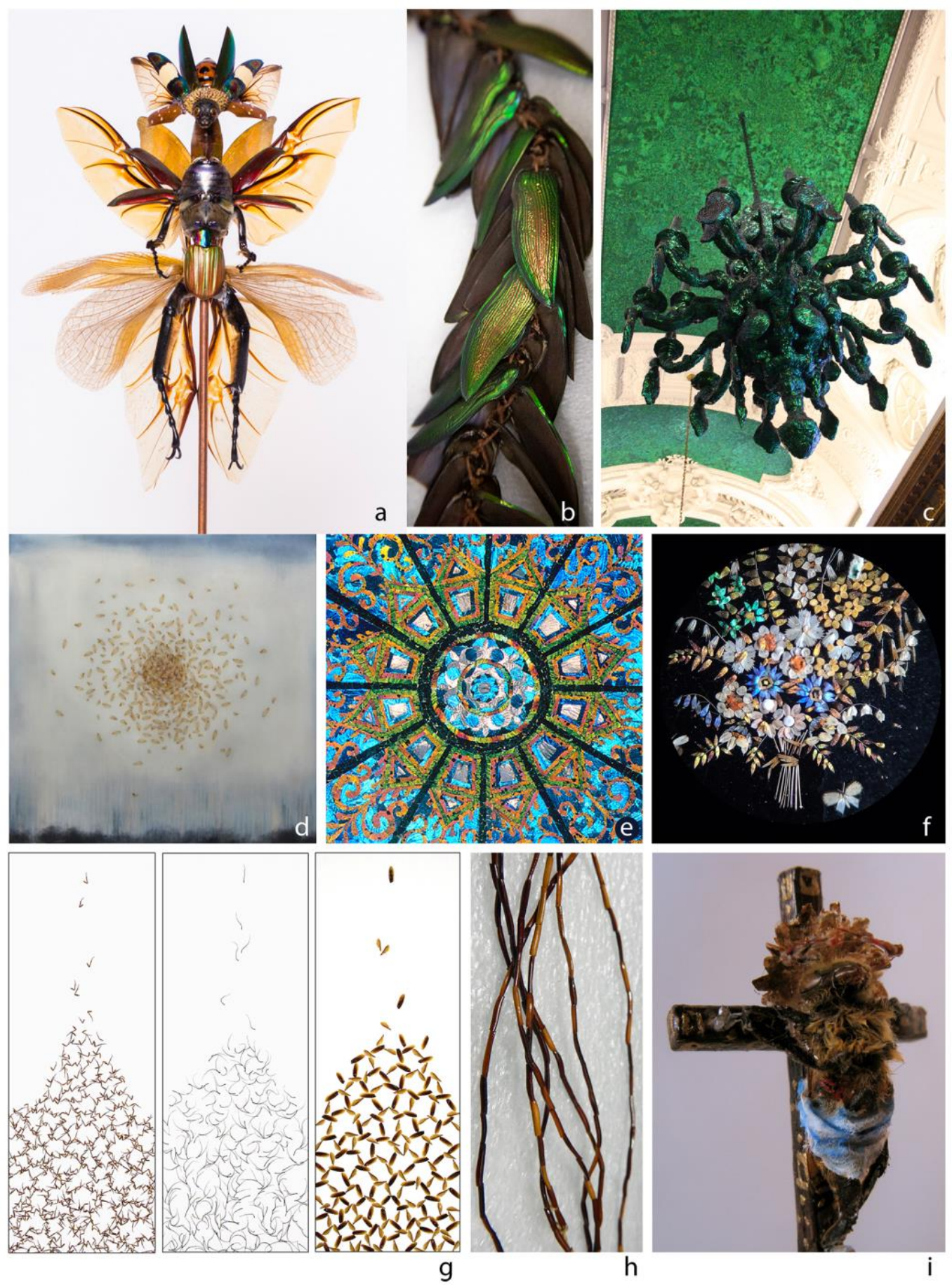

Figure 4. Insect art using insect body parts. Insect chimaera: (a) A "fairy" (Cedric Laquieze), assembled from insect parts. Wings: (b) Ear ornament of beetle elytra (Euchroma gigantea) strung together with tuft of toucan feathers [detail, feathers not visible; acquired 1930; Awajún (Aguaruna) - a Shuar subtribe, Amazon Region, Brazil]; (c) Heaven of Delight (Jan Fabre, with help from 29 assistants, 2002) colors the Hall of Mirrors in the Belgian Royal Palace with 1.6 million metallic green elytra of the jewel beetle Sternocera aequisignata; (d) Pale Dream 7 (Mayme Kratz, 2010) includes epoxy resin-embedded cicada wings; (e) Butterfly wings (detail; Lori Precious, 2003) is a stained glass-inspired mosaic of butterfly wings. 
Wing scales: (f) Bouquet of flowers with butterflies (detail; Henry Dalton, ca. 1875-1900) is the microscopic arrangement of diatoms and individual scales from butterfly wings. Appendages: $(g)$ Pit drawings (Catherine Chalmers, 2003) are arrangements of American cockroach ( $P$. americana) legs, antennae, and wings; $(h)$ necklace of ant leg segments strung on tucum fiber (acquired 1968-1969; Nambikwara, Niyahlósú band, Mato Grosso, Rio Camararé, Aldeia Camararé, Brazil). Armament: (i) Apis Ignota, Operaria Alvi (Judith Klausner, 2009) wears a crown of thorns composed of honey bee stingers. Images courtesy of $(a, d, e, g)$ the artist, $(b, h)$ the author, taken with permission in the collections of The Field Museum of Natural History (catalog \#48807 \& 190825), (c) photographer Gerry Bates, $(f)$ photographer Eva Hausam and The Museum of Jurassic Technology, (i) photographer Brendan DolanGavitt, and the artist.

\section{WHOLE INSECT}

The glorious body forms, shapes, colors, and behaviors, so exquisitely evolved, make insects esthetically wondrous works unto themselves. Without cleaving the segmented bodies, or extracting their products, artists have incorporated the entire bodies, dead or alive, into their work.

\section{Displaying the dead}

Insect carcasses appear as traditional adornments throughout the world, including in Jivaro headdresses in Ecuador (90). The Zulu of southern Africa have strung necklaces of the encysted bodies of immature scale bugs (Margarodes spp.), referred to as "ground pearls" or "ant eggs" because they are found underground, sometimes in ant nests (108; Figure $5 a$ ). Intact insects were also displayed in European cabinets of curiosity, have augmented dioramas in natural history museums, and exist within modern and contemporary art. Some artists have preferred to work with unmodified insects, esthetically arranged together (John Hampson; Jacques Kerchache, 99; Christopher Marley, 73), or in patterns on a grand scale (Sarah Hatton's Bee Works; Damien Hirst's butterflies; Jennifer Angus's room-sized Wunderkammers, 2; Figure $5 b$ ). Others have integrated insects into collages (Pablo Picasso's Composition au papillon, 1932, 72; and works by Alberto Faietti, 33; Laurent Gauthier; The Art Guys, 74; Magnus Muhr; Jo Whaley, 114; Barbara Norfleet, 82), or incorporated insects into sculptures or installations (Jan Fabre; Ann Brodie; Slinkachu, 97; Klaus Enrique; Tessa Farmer, 75; Figure 5 c).

Insects can be modified in minor ways (Jenny Kendler's Companion for Utopians I, 2013), painted with elaborate designs (Akihiro Higuchi), radically mutated (Jan Fabre, 32; Adrienne 
DeLoe; Figure $5 d$ ), turned into gear-laden techno-cyborgs (Mike Libby), implanted with a webserver (Garnet Hertz's Fly with implanted webserver, 2001), or smuggled into a museum and equipped with sidewinder missiles and satellite dish (Banksy's Withus Oragainstus, 2005). Posing dead insects in anthropomorphic scenarios (Ricky Boscarino, 67; Dick Webb, 38; Kevin Clarke) is a practice reminiscent of the clothed fleas in Mexican folk art (75), or Ladislaw Starewicz's early $19^{\text {th }}$-century stop-motion animations with insects (93).

\section{Working with the living}

Click beetles (Elateridae) and Fireflies (Lampyridae) have been captured and used as living, bioluminescing adornments, and small chains have tethered other "living jewels" to clothing in India, Sri Lanka, and Mexico (91). The following are examples of modern and contemporary art in which live insects were on display - engaging in normal behavior, used in (non)traditional practices, manipulated in a collaborative sense, or given control over human technology.

Normal behavior: Observing insects can be a new experience for many art gallery visitors, and artists have brought colonies of ants indoors (Antics; 56), and honey bees to parks [Garnett Puett, Apiscaryatid, 1986; Pierre Huyghe, Untilled (Liegender Frauenakt), 2012], displayed dermestid beetles in a diorama (Ryan Taber and Cheyenne Weaver, In Search Of A Myopic's Lietmotif, Mal'Aria, 2005), and given a synchrotron peepshow of honey bees' innards (Trish Adams, Honeybee Raree Box, 2015). Granted, all of these examples, like Mark Thompson inviting honey bees to cover his head (e.g., Immersion, 1972; 6), involve some significant manipulation of insects' environments. Normal behaviors take conceptual twists when artists entice leaf-cutter ants to carry tiny flags and symbols of peace (Donna Conlon, Coexistence, 2003), or flower petals to a giant sculpted queen (Catherine Chalmers, The Chosen, 2012), or when ants redistribute the colored sands forming flags and other arbitrary symbols of perceived power (Yukinori Yanagi; Figure 5 e). Caddisflies (Trichoptera) construct cases using silk glands, but of gold and semi-precious jewels instead of sticks and stones in Hubert Duprat's insect collaborations (28; Figure 5 f). Aki Inomata followed suit, giving snips of haute fashion to bagworm moths (Psychidae) for them to sew into their cases. "girl, girl, girl..." (2019) features female bagworms in a statement about gender issues, tweaking a traditional Japanese pastime in which children give the bagworms strips of colored paper (50). Catherine Chalmers 
forces viewers to confront what is normal when cockroaches are painted, adorned with feathers, or are subjected to (fabricated) scenes of anthropomorphic executions (16).

Traditional practices: Sericulture is at the core of silk-covered works by Kazuo Kadonaga and $\mathrm{Xu}$ Bing, including series featuring live, silk-spinning larvae (Figure $3 b, c$ ), and the sad state of extreme domestication is on display as male silkworm moths fail to fly to nearby females (Tera Galanti, Hope and Futility, 2006). The flea circus, a dying pastime, was painstakingly revived by María Fernanda Cardoso for live audiences (Figure $5 \mathrm{~g}$ ). Recreational, staged insect battles were alluded to in Combat Cricket Case (Jana Sterbak, 1997) with live crickets, and gruesomely realized in Theater of the World (Huang Yong Ping, 1993), pitting animals, including large insects, against each other.

Collaborations: Interspecific communication is an ethologist's dream, and artists have experimentally explored such aspirations with midges (Ursula Damm, Insect songs, 2018), fruit flies (Damm, Drosophila Karaoke Bar, 2018), and crickets (Evgenija Wassilew, Dissonate, 2010; Amy Youngs, Cricket Call, 1998 and Holodeck, 2007).

Control over technology: The reins of control over human technology, when handed to insects, can offer an element of surprise. Vibrations made by honey bees within a remote hive control the sounds and lighting of Wolfgang Buttress' The Hive (2015). The massive sculpture can flicker or flash, depending on bees' reactions to the time of day and weather. In Garnet Hertz's Cockroach Controlled Mobile Robot \#1 (2004), a single hissing cockroach (Gromphadorhina sp.), positioned on a trackball, can remotely control a robot's movement. When the robot approaches an obstacle, a light flashes in front of the cockroach, and if the (negatively phototropic) cockroach attempts to scurry away, the trackball signals to the robot to evade the imminent threat. 

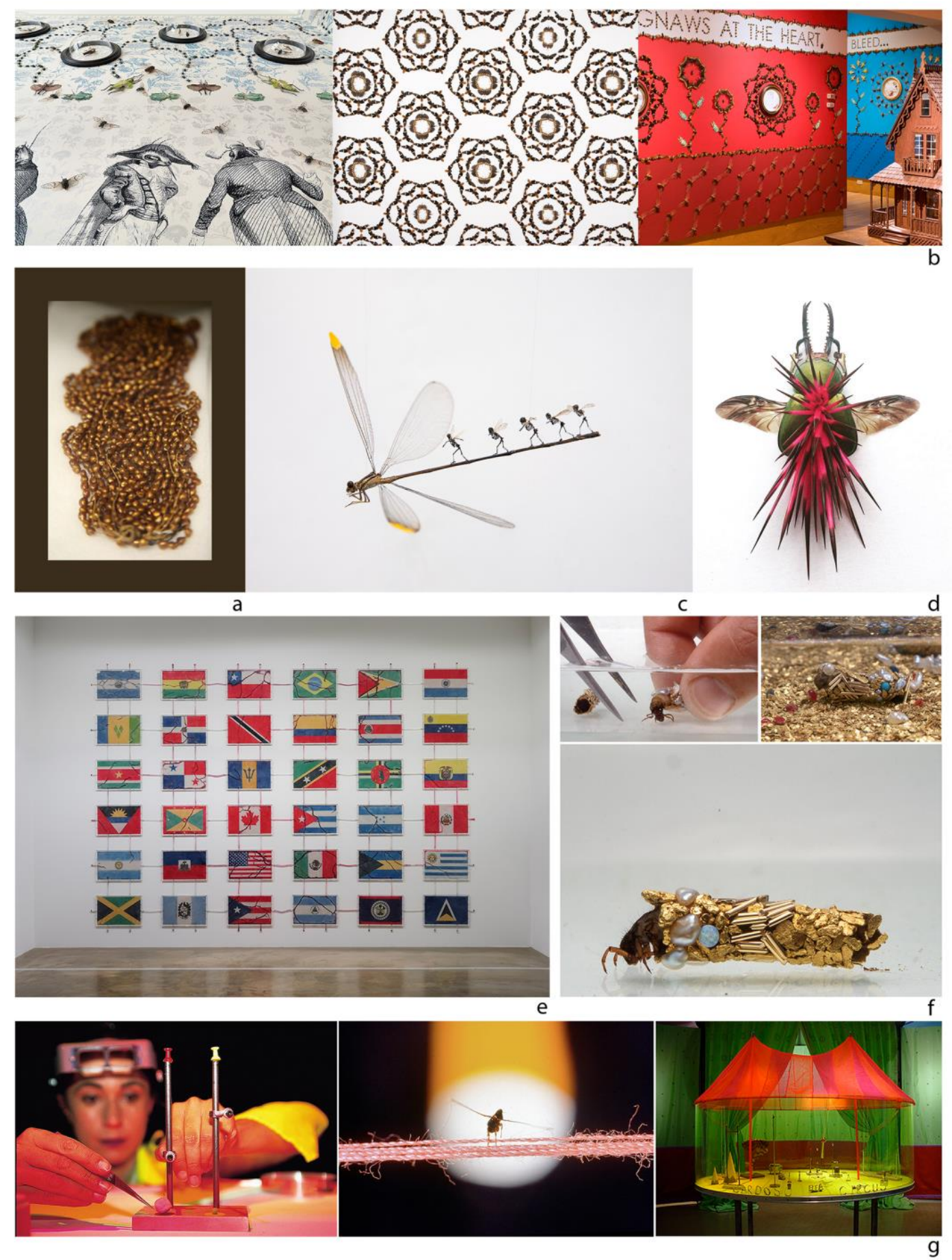

Figure 5. Insect art using whole insect bodies, $(a-d)$ dead or $(e-g)$ alive. Dead: (a) Necklace of "ant eggs" or "ground pearls" (Margarodes sp. nymphs, enclosed within their cysts; acquired ca. 1893; Zulu, southern Africa); views from (b) Hunters and Hunted (2012), A Terrible Beauty Chapter 1 (2005), and A Terrible Beauty Chapter 2 (2006) by Jennifer Angus; (c) The Perilous Pursuit of a Python (Tessa Farmer, 2013) detail, with fairies made out of plant roots and insect wings riding atop a damselfly; $(d)$ Mutation 1 (Adrienne DeLoe, 2019), mixed media with sawtooth beetle (Lamprima adolphinae). Alive: (e) America (Yukinori Yanagi, 1994, (CYanagi Studio) connects flags composed of colored sand in plastic boxes with 
tubes, allowing ants to disperse the sands and break down symbols of political separation; ( $f$ ) Caddisfly larvae (Trichoptera) use silk to construct a case made of gold spangles and semi-precious stones after Hubert Duprat removed their less lustrous original cases; ( $g$ ) Cardoso Flea Circus, with Professor Cardoso / Queen of the Fleas (María Fernanda Cardoso, 2000), Ctenocephalides felis, tight rope artist (1997), and circus arena made by the artist. Images courtesy of $(a)$ the author, taken with permission in the collections of The Field Museum of Natural History (catalog \#28750.1), (b, d,e,f,g) the artist, (c) New Art Gallery Walsall, and the artist.

\section{FUTURE PROSPECTS for insects as art media}

Most insects have never crossed artists' minds or graced their palettes. The wonder or utility of insects or their products presents vast unchartered territory to the artist. With each insect species, described or undescribed, lies a unique evolutionary history, ecological niche, behavioral repertoire, bauplan, and innards. Within every scientific venture lies the potential for artistic replication, interpretation, or reinvention. The only barriers to producing insect media art involve access to insects of choice, and, importantly, ethics of exploiting fellow animals.

\section{Traces}

Traces can be mysterious, foreboding, evocative - perfect fodder for art. The future of recording or managing insect traces is boundless because insects leave hints of their presence almost everywhere. Silverfish (Zygentoma) ingest books, leaving circuitous paths, ostensibly censoring text as they go. Mealworms chew through polystyrene (118). Other insects can devour keratin, leather, or even lead (70). Insect activity could be traced in novel substrates, within a host's body, or by imaging internal processes.

\section{Products}

Glands abound in insects, and insects' bodily constituents are far from completely catalogued or chemically understood. Hymenoptera and Embioptera spin silk, yet I am unaware of any art using silk from these orders (aside from honey bee brood comb fortified by larval silk), or, likewise, the wax of fulgorid bugs or the spittle of spittlebugs. Thomas Eisner cleverly rendered visible the abdominal defensive sprays of bombardier beetles (29), which artists could view as a reference for visualizing an array of insect chemical defenses. There are unexplored colorproducing fluids and pigments that reside within bodies of insects. Thousands of coccoids might hold benefits for artistry, if not industry. Are any of these, or the "tobacco juice" regurgitates of 
grasshoppers light fast? There seems to be potential to elaborate on the practice of offering paper wasps colored paper to produce deviant nests, or to use termite nest material in art. Ricky Boscarino has experimented with mud dauber wasp nests, firing them in a kiln, even glazing a few (Boscarino, pers. comm.). Engineering and design efforts are exploring uses of chitin, the polysaccharide that fortifies insect exoskeletons, as a bioplastic (41) and the material of choice for future spacecraft (49). The lines drawn between science, technology, and art are often blurred, particularly when it comes to experimenting with products like silk (39). If silk is not strong enough for artistic applications, or not the desired color, you can feed B. mori larvae carbon nanotubes (112), or slip dye into their food (80)! Some designers are contemplating "natural printing" by honey bees on the scale of buildings (45).

\section{Body parts}

It may appear that artists have exploited every anatomical feature of insects, but insect armaments rarely appear in art, nor does iridescence from non-elytra sources.

\section{Whole insect}

Artists can explore traditional methods for preparing insect specimens for display (115), or consider modern technical approaches. Science is revealing strange ways in which insects can be altered, including bioengineering insects to fluoresce when a heat-sensitive protein is activated, even laser-etching a pattern on a butterfly wing (89). Cyborgs and remotely-controlled insects are no longer science fiction (96). Catherine Chalmers wonders if we could "engineer [cockroaches] to look like a favorite insect, or mammal, or perhaps the kitchen wallpaper (16)." Lower-tech options include luring insects with pheromone or sugar water to form living symbols or words, as described by Katherina Meldner (77), or passively coloring insects (107).

\section{BIODIVERSITY OF INSECT MEDIA ART}

Countless works by innumerable artists have been coated in shellac, colored with carmine, or created using silk, and most encaustic paintings use beeswax. Although the hidden, incidental use of shellac, carmine, silk, and beeswax dominate insect media art, it is the intentional use of insect media that may be most compelling, and makes up all examples in Figures 2-6 and Table S1. I surveyed art by 158 artists that intentionally includes insect traces, products, body parts, or 
entire bodies (Table S1). I then analyzed works by 115 of these artists (see Figure 6 for details), which summed to 157 examples of insect media art, each example lumping together works grouped by artist, insect order, and the category of insect use (e.g., all of Damien Hirst's art with butterfly wings = 1 example); 58 examples were in the category of insect "products," 33 in "body parts," 33 in "dead," and 33 in "live" (Figure 6). Calculations exclude work by artists who have used $>3$ insect orders. By excluding these, and by binning artists' works into "examples," as described above, the influence of one artist on the survey's calculations is limited (83 of 115 artists are represented only once). Of the 15 insect orders reported (12 eligible for analysis), Hymenoptera comprised the greatest proportion of examples (59 of 157, 38\%), followed by Lepidoptera (44 of 157, 28\%). A. mellifera honey bees accounted for most examples - a total of 45 of the 59 uses of Hymenoptera, and B. mori accounted for 14 of 44 uses of Lepidoptera. Hymenoptera and Lepidoptera contributed to almost two-thirds (66\%) of the examples of insect media art that explicitly or conceptually featured insects.

If number of species correlated with insect use in art, beetles would dominate. If proximity to insect multitudes were the primary catalyst compelling humans to include insects in art, we might expect ants, flies, or ectoparasitic orders to dominate insect media art, yet the western honey bee and the domestic silkworm disproportionately capture the attention of artists. It is no coincidence that a bias favored the two insect species with the most extensive history of exploitation by humans. Different associations can develop from our connections with, or dependence on insects, so even with respect to these two species, artists' reasons for using them can vary tremendously, or represent a complex mix of incentives. Despite artists' overwhelming attention to Hymenoptera and Lepidoptera, diversity within insect media art undoubtedly exceeds 15 orders, but examples beyond those reported here are expected to be scarce, or hidden among work by artists who have used multiple insect orders. 


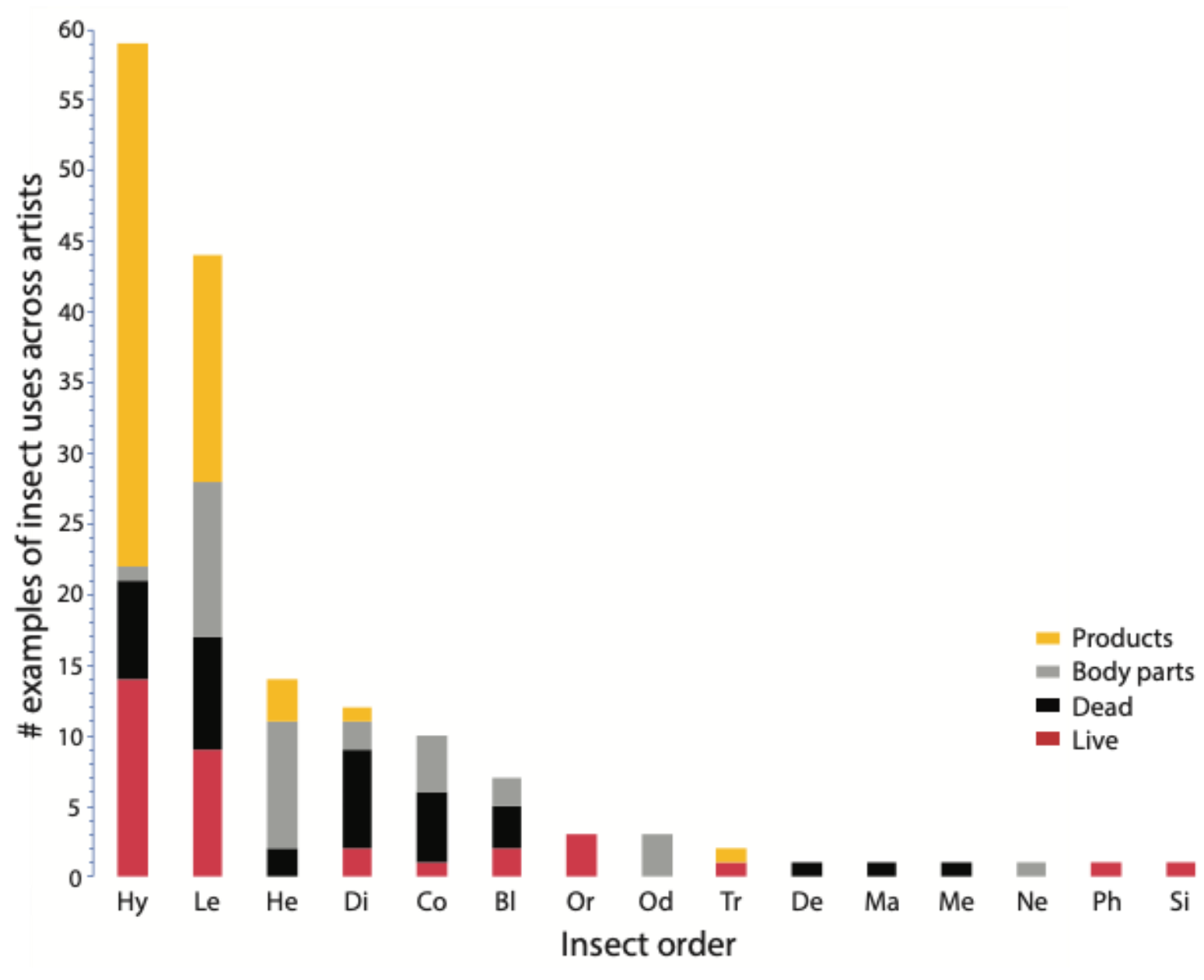

Figure 6. Number of examples across artists in which different orders were used live, dead, for their body parts, or products. Survey includes 157 examples of insect media art by 115 (of 158) artists, each example lumping together works grouped by artist, insect order, and the category of insect use. All works relate to insects explicitly or conceptually (Table S1). Artists whose work features only insect "traces" are excluded here $(n=8)$, as are the remaining artists who have worked with more than three orders of insects $(n=$ $33)$, or whose works include only anonymous insect orders $(n=2)$. Dermaptera, Mantodea, and Siphonaptera are included in the graph, but are excluded from calculations in the text because the artists using these insects have used $>3$ insect orders. Ordinal abbreviations: $\mathrm{BI}=$ Blattodea, $\mathrm{Co}=$ Coleoptera, $\mathrm{De}$ $=$ Dermaptera, $\mathrm{Di}=$ Diptera, $\mathrm{He}=$ Hemiptera, $\mathrm{Hy}=$ Hymenoptera, Le = Lepidoptera, $\mathrm{Ma}=$ Mantodea, $\mathrm{Me}=$ Megaloptera, $\mathrm{Ne}=$ Neuroptera, $\mathrm{Od}=$ Odonata, $\mathrm{Or}=$ Orthoptera, $\mathrm{Ph}=$ Phasmida, $\mathrm{Si}=$ Siphonaptera, $\mathrm{Tr}=$ Trichoptera.

\section{ETHICS}

Now that we've pondered some insect media art possibilities, it is important to consider the ethics of using organisms - any organisms-in the creation of art. Insects breathe, reproduce, respond to external stimuli, learn, communicate, and some can live decades. The question of what it means to be sentient, conscious, or to feel pain are all contentious, and unresolved when 
it comes to insects. Human-induced extinction rates are increasing alarmingly (111) and each loss, aside from having ecological consequences, means lost potential to appreciate an insect, including artistically. It is imperative that humans, including artists, practice responsible, sustainable use of insects or insect products for the sake of preserving insect diversity and abundance, respecting their implicit value, realizing their known and unknown ecological roles, or investing in future anthropocentric attributes (material, medical). Ethical codes of conduct vary in arbitrary ways across political boundaries, so abiding by local laws or guidelines of handling animals is the absolute moral minimum one should adopt when producing insect media art. Where artists and purveyors of art draw their lines is, however, a relative exercise. When asked what questions they receive most frequently about their art, 7 of 12 respondents whose work is featured in this review cited questions related to how their insects were acquired or about the treatment of the insects. This concern is explicitly addressed on some of the artists' websites (Table S1), usually within the context of sustainability. Some use insects found dead (Farmer, Kratz), from their own colonies (Chalmers), or from state-run extermination efforts (Peña), and others are harvested from the wild (Angus), farmed (Laquieze, some of Hirst's works), or recovered as leftovers from human food (Fabre, at least as reported for Heaven of Delight; Figure $4 c$ ). Huissard makes a point of using silkworm moth cocoons without killing the inhabitants. Notable exceptions to this mindfulness about the treatment of insects exist and some can inspire outrage, like Huong Yong Ping's staged insect battles in Theater of the World (1993), or not, even as thousands died in Damien Hirst's A Thousand Years (1992) or Mark Dion's The Great Munich Bug Hunt (1993). A sobering response to Hirst's critics comes from Giovanni Aloi (1), reminding us that most art has hidden animal sacrifices - ox gall (bovine gall bladder extract) in watercolor, egg in tempera, squid ink for sepia, rabbit for canvas glues, and various mammals for brushes - and that art can stimulate a reassessment of our relationship with nature. Insect media art can inspire us to reassess, for example, the value of nature by promoting awareness of biodiversity.

\section{CONCLUSIONS}

This review introduces the history, value, and breadth of insect media art, including the many ways artists have harvested, studied, exploited, or collaborated with insects for their potential uses. It also considers the ethics associated with this art, and speculates about untapped potential 
for future artists wishing to explore, experiment with, and exhibit the peculiar, the utilitarian, and the marvels around us, bound in the bodies of the most diverse lineage of life on Earth. Far from comprehensive, as a survey this offers a starting point to uncover a hidden wealth of insect use in art. As an interdisciplinary topic, the study of insect media art can be as much a foray into material science, biomimetics, insect morphology, or behavior as it can be into art history. Science and the arts have the potential to mutually benefit from exchanges relevant to insect media art, including, as with any truly interdisciplinary venture, cultivating the possibility for novel discovery. Art offers a potent capacity to evoke emotions, provide perspective, or inspire humans to act, and art - prehistoric to contemporary - owes a surprising debt to insects and the products they yield.

\section{DISCLOSURE STATEMENT}

The author is not aware of any affiliations, memberships, funding, or financial holdings that might be perceived as affecting the objectivity of this review.

\section{ACKNOWLEDGMENTS}

I dedicate this article to the memory of Sue Hubbell, who wrote about the wonders of arthropods with respect, grace, humor, and clarity. Her discovery of "Bug Art" (46) exposed me to the under-appreciated world of insect media art. I am especially grateful to all of the artists who shared their work or their personal approaches or perspectives related to creating insect art. Lynette Korenic, Robin Rider, Yavuz Parlar, Penny Gullan, Demian Kondo, John Abbott, and Alex Wild provided information, and Christopher Philipp and Daniel Le generously gave me access to relevant artifacts from the collections of the Field Museum of Natural History. Kevin Tougeron, Steven Kutcher, Mary Glasper, Abe Packard, and Dosha Klein gave helpful feedback on an earlier draft of this manuscript. 


\section{LITERATURE CITED}

1. Aloi G. 2019. The misplaced outrage over Damien Hirst's dead butterflies. Apollo. https://www.apollo-magazine.com/damien-hirst-dead-butterfly-wings-outrage/

2. Angus J. 2008. A Terrible Beauty. Toronto, Canada: ABC Art Books of Canada

3. Appleton A. 2015. Insectophilia. Aeon. https://aeon.co/essays/japanese-cultureconquered-the-human-fear-of-creepy-crawlies

4. Ballengée B, Bittle J, Clark R, Clark E, Greene T, et al. 2013. Notched Bodies: Insects in Contemporary Art. New York, NY: The Arsenal Gallery

5. Barbara Walton Artist. Barbara Walton. https://barbaraewalton.com

6. Bartlett M, Fried H, Roloff J, Thompson M. 2000. Monopoly: page one. New Observations, pp. 19-60

7. Bégouen le comte, Bégouen L. 1928. Découvertes nouvelles dans la Caverne des Trois Frères a Montesquieu-Avantès (Ariège). Revue Anthropologique. 33:358-64

8. Berbers SVJ, Tamburini D, van Bommel MR, Dyer J. 2019. Historical formulations of lake pigments and dyes derived from lac: A study of compositional variability. Dyes and Pigments. 170:107579

9. Blas M, Hoyo JD. 2013. Entomología cultural y conservación de la biodiversidad: los insectos en las artes mayores. Cuadernos de Biodiversidad. 42:1-22

10. Bonaduce I, Colombini MP. 2004. Characterisation of beeswax in works of art by gas chromatography-mass spectrometry and pyrolysis-gas chromatography-mass spectrometry procedures. Journal of Chromatography A. 1028(2):297-306

11. Brecoulaki H, Andreotti A, Bonaduce I, Colombini MP, Lluveras A. 2012. Characterization of organic media in the wall-paintings of the "Palace of Nestor" at Pylos, Greece: evidence for a secco painting techniques in the Bronze Age. Journal of Archaeological Science. 39(9):2866-76

12. Bristowe WS. 1974. Art on a cobweb. Animals. 16:61-62

13. Brückner D, Rothhaar B. 2010. Bee Spaces: Honeybees in Art and Science. Bremen, Germany: Haus der Wissenschaft

14. Cassirer I. 1956. Paintings on cobwebs. Natural History, pp. 202-20

15. Castro R, Miranda A, Melo MJ. 2016. Interpreting lac dye in medieval written sources: new knowledge from the reconstruction of recipes relating to illuminations in Portuguese manuscripts. In Sources in Art Technology: Back to Basics, pp. 88-99. Oxford, UK: Archetype Books

16. Chalmers C. 2004. American Cockroach. New York, NY: Aperture Foundation, Inc.

17. Chang K. 2014. How this Renoir used to look. The New York Times, April 20. https://www.nytimes.com/2014/04/22/science/renoir-shows-his-truecolors.html?searchResultPosition $=2$

18. Cherry RH. 1991. Use of insects by Australian Aborigines. American Entomologist. 37:813

19. Cloudsley-Thompson JL. 1976. Insects and History. New York, NY: St. Martin's Press

20. Collier R, Kosaka H. 2001. Kazuo Kadonaga. Los Angeles, CA: Japanese American Cultural and Community Center

21. Craig CL. 1997. Evolution of arthropod silks. Annu. Rev. Entomol. 42(1):231-67

22. Darwin CR. 1859. On the Origin of Species by Means of Natural Selection, or the Preservation of Favoured Races in the Struggle for Life. London: John Murray. 1st ed. 
23. Dathe S, Ullrich J. 2012. Hunters and Hunted. Biberach an der Riß, Germany: Biberacher Verlagsdruckerei

24. Davies M, Kathirithamby J. 1986. Greek Insects. New York, NY: Oxford University Press

25. Delcomyn F. 2004. Insect walking and robotics. Annu. Rev. Entomol. 49(1):51-70

26. Denton SF. 1900. As Nature Shows Them: Moths and Butterflies of the United States, East of the Rocky Mountains; with over 400 Photographic Illustrations in the Text and Many Transfers of Species from Life. Boston: Bradlee Whidden

27. Dicke M. 2000. Insects in Western art. American Entomologist. 46:228-36

28. Duprat H. 2020. The Caddisfly's Mirror. Lyon, France: Fage éditions

29. Eisner T. 2003. For Love of Insects. Cambridge, Mass: The Belknap Press

30. Entin CL, Tobin EN. 1976. Butterfly printing: a new-old process for preserving and displaying lepidopteran wings on paper. Insect World Digest. 3(6):18-23

31. Everts S. 2016. Van Gogh's fading colors inspire scientific inquiry. Chemical \& Engineering News. 94(5):9

32. Fabre J. 2004. Trilogie. Salzburg, Austria: Academia Galerie und Verlags

33. Faietti A. 1989. Cenere d'Argento. Milano, Italy: Gabriele Mazzotta

34. Feller RL, National Gallery of Art, eds. 2012. Artists' Pigments: A Handbook of their History and Characteristics. Vol. 1. Washington, DC: National Gallery of Art. https://www.nga.gov/research/publications/pdf-library/artists-pigments-vol-1.html

35. Fuchs I. 2019. Flügelshlag: Insekten in der zeitgenössischen Kunst. Museum Sinclair-Haus

36. Genosko G, Lewis D, Reid M. 2005. Bug City. Winnipeg, Canada: The Winnipeg Art Gallery

37. Gökbel M. 2018. Usage of insect as image in contemporary ceramic art. Sanat ve Tasarım Dergisi. 8(2):206-25

38. Gordon DG. 1996. The Compleat Cockroach: A Comprehensive Guide to the Most Despised (and Least Understood) Creature on Earth. Berkeley, CA: Ten Speed Press

39. Group Projects «Mediated Matter. MIT Media Lab. https://www.media.mit.edu/groups/mediated-matter/projects/

40. Hilloowala R, Lanza B, Puccetti MLA, Poggesi M, Martelli A. 1995. The Anatomical Waxes of La Specola. Florence, Italy: Arnaud Ed.

41. Hobson B. 2013. Young designers transform beetles into plastic and printing ink. Dezeen. https://www.dezeen.com/2013/11/14/movie-red-ink-made-from-cochineal-insectsand-bio-plastic-from-beetles/

42. Hogue CL. 1968. Butterfly wings: living pointillism. Los Angeles Museum of Natural History Quarterly. 6(4):4-7

43. Hogue CL. 1980. Commentaries in cultural entomology. 1. Definition of cultural entomology. Entomological News. 91(2):33-36

44. Hogue CL. 1987. Cultural Entomology. Annu. Rev. Entomol. 32:181-99

45. Howarth D. 2014. Bees could 3D-print "concrete honey." Dezeen. https://www.dezeen.com/2014/07/27/bees-3d-printing-concrete-geoff-manaughjohn-becker/

46. Hubbell S. 1987. Bugs. The New Yorker, pp. 79-89. https://www.newyorker.com/magazine/1987/12/28/bugs

47. Huissoud M. Marlene Huissoud. Marlene Huissoud. https://www.marlene-huissoud.com

48. Hulcr J. Bark Beetle Calligraphy. Bark Beetle Calligraphy. http://www.ambrosiasymbiosis.org/calligraphy/ 
49. Hurley B. A Bug-inspired building material for Mars. Here's an Idea. https://www.techbriefs.com/component/content/article/tb/webcasts/podcasts/3809 $4 ? \mathrm{~m}=1401$

50. Inomata A. Aki Inomata Official Site. Aki Inomata Official Site. https://www.akiinomata.com/

51. Irwin ME, Kampmeier GE. 2003. Commercial products from insects. In Encyclopedia of Insects, pp. 251-60. San Diego, CA: Academic Press

52. Jeanne RL. 2003. Nest building. In Encyclopedia of Insects, pp. 778-82. San Diego, CA: Academic Press

53. Kaufmann TD, Kaufmann VR. 1991. The sanctification of nature: observations on the origins of trompe l'oeil in Netherlandish book painting of the fifteenth and sixteenth centuries. The J. Paul Getty Museum Journal. 19:43-64

54. Kennedy R. 2009. Gossamer silk, from spiders spun. The New York Times, Sep. 22. https://www.nytimes.com/2009/09/23/arts/design/23spiders.html

55. Khatun S, Mohal Khan GRMA, Rahman ML, Hossain K, Islam MdJ, Akhtar A. 2014. Isolation and utilization of natural dye (lac dye and Arjun dye). IOSRJAC. 7(2):74-76

56. Klein BA. 2003. Par for the palette: insects and arachnids as art media. In Insects in Oral Literature and Traditions, pp. 176-96. Dudley, MA: Peeters. https://www.researchgate.net/publication/216756705_Par_for_the_palette_Insects_an d_arachnids_as_art_media

57. Klein BA. 2007. Insects and Humans: a relationship recorded in visual art. In Encyclopedia of Human-Animal Relationships. Portsmouth, NH: Greenwood Publ. https://www.researchgate.net/publication/216757251_Insects_and_humans_a_relatio nship_recorded_in_visual_art

58. Klein BA. 2013. Standing on the shoulders of wee giants. In ECLOSION: a juried group exhibition of insect-inspired art. Austin, TX: Art.Science.Gallery. http://issuu.com/artsciencegallery/docs/eclosioncatalogue

59. Klein BA. 2015. Encaustics: repurposing the architecture of insects. In The Buzz Stops Here: an exhibition of encaustic artwork about the science and conservation of bees. Austin, TX: Art.Science.Gallery. http://issuu.com/artsciencegallery/docs/buzzcatalogue_20150411_1608

60. Klein BA, Brosius TR. In press. Insects in art during an age of environmental turmoil. In A Cultural History of Insects in the Modern Age. London: Bloomsbury Publ.

61. Kritsky G. 2017. Beekeeping from antiquity through the Middle Ages. Annu. Rev. Entomol. 62(1):249-64

62. Kritsky G, Mader D. 2010. Leonardo's insects. American Entomologist. 56(3):178-84

63. Kritsky G, Mader D. 2011. The Insects of Pieter Bruegel the Elder. American Entomologist. 57(4):245-51

64. Kritsky G, Mader D, Smith JJ. 2013. The insect imagery of Salvador Dali. 59(1):28-37

65. Kritsky G, Smith JJ. 2018. Insect biodiversity in culture and art. In Insect Biodiversity, pp. 869-98. Chichester, UK: John Wiley \& Sons, Ltd

66. Leggett H. 2009. 1 million spiders make golden silk for rare cloth. Wired. https://www.wired.com/2009/09/spider-silk/

67. Levine R. 2012. Roaches and brooches: the insect art of Ricky Boscarino. American Entomologist. 58(3):183-86 
68. Lockwood JA. 2012. Insects as weapons of war, terror, and torture. Annu. Rev. Entomol. 57(1):205-27

69. MacVean C. 2008. Lacquers and dyes from insects. In Encyclopedia of Entomology, pp. 2110-17. Dordrecht, Netherlands: Springer

70. Magni PA, Voss SC, Testi R, Borrini M, Dadour IR. 2015. A biological and procedural review of forensically significant Dermestes species (Coleoptera: Dermestidae). J Med Entomol. 52(5):755-69

71. Malkin E. 2017. An insect's colorful gift, treasured by kings and artists. The New York Times. https://www.nytimes.com/2017/11/27/arts/design/red-dye-cochinealtreasure-mexico-city-history.html?mwrsm=Email\&_r $=0$

72. Manos-Jones M. 2000. The Spirit of Butterflies: Myth, Magic, and Art. New York: Harry N.Abrams, Inc.

73. Marley C. 2015. Biophilia. New York: Abrams

74. Massing J, Galbreth M. 1995. The Art Guys: Think Twice. New York, NY: Harry N. Abrams Inc.

75. McAra C. 2016. In Fairyland: The World of Tessa Farmer. London: Strange Attractor Press

76. McInerney T, Kossak SM. 2016. Divine Pleasures: Painting from India's Rajput Courts. https://enfilade18thc.com/2016/06/24/exhibition-divine-pleasures-painting-fromindias-rajput-courts/

77. Meldner K. 1983. Aus dem Leben der Ameisen. Berlin, Germany: Galerie ZellermayerLorenzen

78. More D. 1976. The Bee Book. New York: Universe Books

79. Moret P. 1996. Los insectos en el arte Ibérico (siglos III a I a.C.). Boletín de la SEA. 15:63-65

80. Nisal A, Trivedy K, Mohammad H, Panneri S, Sen Gupta S, et al. 2014. Uptake of azo dyes into silk glands for production of colored silk cocoons using a green feeding approach. ACS Sustainable Chem. Eng. 2(2):312-17

81. Noble JV. 1975. The wax of the lost wax process. American Journal of Archaeology. 79:368-69

82. Norfleet B. 1999. The Illusion of Orderly Progress. New York: Alfred A. Knopf, Publ.

83. Pagès E. 2001. Aganetha Dyck. Paris, France: Services culturels de l'Ambassade du Canada

84. Parikka J. 2010. Insect Media: An Archaeology of Animals and Technology. Minneapolis, MN: University of Minnesota Press

85. Parry EJ, Coste JH. 1902. The Chemistry of Pigments. London: Scott, Greenwood \& Co.

86. Peigler RS. 1994. Non-sericultural uses of moth cocoons in diverse cultures. 3(5):1-20

87. Phipps E. 2010. Cochineal red: the art history of a color. The Metropolitan Museum of Art Bulletin

88. Preston C. 2006. Bee. London: Reaktion Books

89. Ramos DM, Kamal F, Wimmer EA, Cartwright AN, Monteiro A. 2006. Temporal and spatial control of transgene expression using laser induction of the hsp70 promoter. BMC Dev Biol. 6(1):55

90. Ratcliffe BC. 2006. Scarab beetles in human culture. The Coleopterists Bulletin. 60:85101

91. Rivers V. 1993. Beetle wings: jewels of nature. Fiberarts. 19(5):52-56 
92. Rooney EA. 2017. Bugs in Contemporary Art: Inspired by Insects. Atgen, PA: Schiffer Publishing, Ltd.

93. Schneider E. 2000. Entomology and animation. Animation World Magazine, pp. 8-13

94. Schwarz HF. 1945. The wax of stingless bees (Meliponidæ) and the uses to which it has been put. Journal of the New York Entomological Society. 53(2):137-44

95. Schweppe H, Roosen-Runge H. 1986. Carmine-cochineal carmine and kermes carmine. In Artists' Pigments: A Handbook of their History and Characteristics. 1:255-83. London: Archetype Publications, Ltd.

96. Shupack A. 2012. How to build your own cockroach cyborg. Popular Science. https://www.popsci.com/science/article/2012-12/how-build-your-own-cockroachcyborg/

97. Slinkachu. 2008. Little People in the CIty: The Street Art of Slinkachu. London: Boxtree

98. Smiles S. 2005. Insects in the history on Western art. Antenna. 29(2):118-20

99. Sottsass E. 2000. Jacques Kerchache: Nature Démiurge Insectes. Paris, France: Fondation Cartier pour l'art contemporain

100. Spencer WB, Gillen FJ. 1899. The Native Tribes of Central Australia. London: MacMillan. https://archive.org/details/nativetribesofce00spenuoft

101. Stearman AM, Stierlin E, Sigman ME, Roubik DW, Dorrien D. 2008. Stradivarius in the jungle: traditional knowledge and the use of "black beeswax" among the Yuquí of the Bolivian Amazon. Human Ecology. 36(2):149-59

102. Steiner R. 1998. Bees. Hudson, NY: Anthroposophic Press

103. Sutherland TD, Young JH, Weisman S, Hayashi CY, Merritt DJ. 2010. Insect silk: one name, many materials. Annu. Rev. Entomol. 55(1):171-88

104. Takeda S. 2003. Sericulture. In Encyclopedia of Insects, pp. 1027-29. San Diego, CA: Academic Press

105. The Museum of Contemporary Art. 2013. John Knuth - Fly Paintings - The Artist's Studio - MOCAtv. https://www.youtube.com/watch?v=jHEXAsflhbA\&t=6s

106. The Museum of Jurassic Technology. The Life and Work of Henry Dalton. The Museum of Jurassic Technology. https://www.mjt.org/exhibits/dalton/dalton.html

107. Thoms EM, Eger JE, Messenger MT, Vargo E, Cabrera B, et al. 2019. Bugs, baits, and bureaucracy: completing the first termite bait efficacy trials (quarterly replenishment of noviflumuron) initiated after adoption of Florida Rule, Chapter 5E-2.0311. American Entomologist. 55(1):29-39

108. Trimen R. 2009. XVIII. Notes on insects apparently of the genus Margarodes, Lansd.Guilding, stated to occur abundantly in the nests of white ants, and also of true ants, in certain western districts of the Cape Colony. Transactions of the Royal Entomological Society of London. 34:461-64

109. Tschinkel WR. 2015. The architecture of subterranean ant nests: beauty and mystery underfoot. J Bioecon. 17(3):271-91

110. Tschinkel WR. 2021. Ant Architecture: The Wonder, Beauty, and Science of Underground Nests. Princeton, NJ: Princeton University Press

111. Wagner DL. 2020. Insect declines in the Anthropocene. Annu. Rev. Entomol. 65(1):45780

112. Wang Q, Wang C, Zhang M, Jian M, Zhang Y. 2016. Feeding single-walled carbon nanotubes or graphene to silkworms for reinforced silk fibers. Nano Lett.16(10):66956700 
113. Watts P. 2004. Bug-Eyed: Art, Culture, Insects. Redding, CA: Turtle Bay Exploration Park

114. Whaley J. 2008. The Theater of Insects. San Francisco, CA: Chronicle Books

115. Wood AA. 1958. Preparing Insect Displays. Ottawa, Canada: Canada Department of Agriculture

116. Woodger M. 2012. Insects in the art and mythology of ancient Mesoamerica (part 2). Antenna. 36(2):96-101

117. Wulf A. 2016. The woman who made science beautiful. The Atlantic. https://www.theatlantic.com/science/archive/2016/01/the-woman-who-madescience-beautiful/424620/

118. Yang Y, Yang J, Wu W-M, Zhao J, Song Y, et al. 2015. Biodegradation and mineralization of polystyrene by plastic-eating mealworms: Part 1. chemical and physical characterization and isotopic tests. Environ. Sci. Technol. 49(20):12080-86

\section{Terms \& definitions:}

Carmine: coloring made from cochineal or kermes bugs that has been purified and prepared (boiled, insoluble matter removed, etc.)

Carminic acid: primary coloring agent in cochineal; used by insect as defense against predators Cochineal extract: pigment made from raw, dried, pulverized cochineal bugs

Cultural entomology: study of insects' influence on the arts and humanities; activities "humans practice for the nourishment of the mind and soul" (43)

Dye: water-soluble, liquid coloring agent

Encaustic: art of painting with heated, pigmented wax (traditionally beeswax)

Ethnoentomology: applications of insect life in "traditional" societies; not synonymous with cultural entomology, according to Hogue, because it includes survival practices (44)

Ink: solution containing a coloring agent (e.g., dye or pigment) used for drawing, writing, or printing

Lacquer: liquid/paste derived mostly from plants (see insect exceptions) that dries to form semitransparent protective or decorative coatings (69)

Pigment: dry, particulate, insoluble material used as a coloring agent

Propolis: honey bees' mixture of plant exudate, beeswax, and saliva, used primarily to fill gaps in nest or hive 
Saliva: proteinaceous oral secretion (52)

Sericulture: industry of cultivating mulberry trees and rearing silkworm moths to produce cocoons (104)

Shellac: processed from lac bug resin; not to be confused with lacquer or "true lacquer," most of which is of plant origin

Silk: proteins with highly repetitive amino acid sequences, stored as liquid and secreted as fibers by insects, spiders, and millipedes (21)

\section{Reference annotations:}

(Hogue 1980)

Charles Hogue first defines cultural entomology.

(Chang 2014)

Renoir painting, digitally reconstructed to reveal palette before cochineal pigment faded, shows drastic difference.

(Hubbell 1987)

The year of Hogue's review, Sue Hubbell writes about the practice of "bug art."

(Klein 2003)

My early attempt at surveying insects as art media includes additional arachnid examples.

(Klein and Brosius, in press)

For cultural entomology volume (modern era): Art about human-induced environmental destruction that features insects.

(Parry \& Coste 1902).

This guide to the chemistry of pigments includes recipes for insect dyes.

(Preston 2006)

The Animal series (Reaktion Books) includes several volumes of arthropods, each full of cultural entomology.

(Duprat 2020)

Hubert Duprat's magnum opus is an esthetically stunning celebration of Trichoptera.

(Klein 2015)

Encaustics exhibit catalog, featuring exclusively work explicitly or conceptually relevant to bees and bee conservation.

(McAra 2016)

Essays related to the strange and remarkable world of Tessa Farmer's fairy art. 


\section{Related resources:}

Ball GE. 2005. The Art of insect illustration and Threads of Entomological History. Edmonton, Canada: The University of Alberta Libraries

Berenbaum MR. 1995. The Bugs in the System: Insects and their Impacts on Human Affairs. Reading, MA: Helix Books

Clausen LW. 1954. Insect Fact and Folklore. New York, NY: The MacMillan Co.

Klein BA. 2012. The curious connection between insects and dreams. Insects. 3:1-17. doi:10.3390/insects3010001. http://www.mdpi.com/2075-4450/3/1/1/

Klein BA, Klein A. 2016. Insects Incorporated: Database of Cultural Entomology. http://culturalentomology.org/

Sear D. Cultural Entomology Digest. http://culturalentomology.com/ced/ (Future home to be decided.) 